\title{
Speeches by Moroccan Companies on Their Practice of Corporate Social Responsibility
}

\author{
Amine Bouchikhi ${ }^{1}$, Youssef Khatori ${ }^{2}$, Hindou Baddih ${ }^{3}$ \\ ${ }^{I}$ PhD student, FSJES, University Ibn Tofail, Kenitra. Morocco \\ ${ }^{2}$ Professor Researcher, FSJES, University Ibn Tofail, Kenitra. Morocco \\ ${ }^{3}$ Professor Researcher, Vice-Dean of Research, FSJES, University Ibn Tofail, Kenitra. Morocco
}

\begin{abstract}
The Corporate Responsibility towards employees, today takes a major stake in the construction of the overall strategy. The subject of our article, is to make a comparison of speech on responsible for human resources management of companies, between two different sectors to Morocco on one side than the bank, and another one telecoms. The methodology is qualitative and consists of a thematic discourse analysis of three telecom operators, and its comparison with that of banks, concluding with a cognitive mapping for both sectors. The main strategic trends that emerge in each sector: A logical minimalist efficiency to the telecoms sector, and a trend towards a strategic positioning for banks.
\end{abstract}

Keywords: RHRM, CSR, telecoms, banks, speech, cognitive mapping, thematic analysis, strategic trend

\section{Introduction}

Responsible management of human resources and social responsibility towards employees is considered an essential dimension of CSR. Of academic effort has been invested in recent years to rethink Human Resource Management (SHRM), to take account of the imperative ethics and CSR. On the other hand, the imposing theorizing social performance company founded on the ethical and normative theory of stakeholders, site workers among the main beneficiaries to the interests as legitimate as the annuitants of the firm. From the practical side, the CSR performance criteria in the matter of winning both the lawful obligations by voluntary standards, include those related to the thematic of employment and respect for workers' rights. The speech of the companies on their responsible practices (see for example Lovasoa Ramboarisata et al., 2008 ; De Serres et al., 2006; Vuontisjarvi, 2006), of their employees and issues about (eg health and safety, professional development, diversity of the workforce etc.) is the manifestation of responsible behavior the same way as the integration of environmental considerations, community and ethical. Nevertheless like CSR and constitutes an important dimension, the responsible management of human resources or social responsibility towards employees, remains a clear up.

In this paper, it is first of all to clear the strategic trend of speeches operative enterprises in the telecommunications sector in Morocco, in matters of Social Responsibility towards employees based on the strategic management of human resources before comparing this trend with that of Moroccan Banks, studied in our first article ${ }^{1}$.

So the main question that emerges, in this sense, is: «What are the similarities and differences between the discourse of banks and telecoms operators in Morocco in matters of Social Responsibility towards employees?»

To answer this question we propose: First to study the shape of the CSR reports of networks operators; then recalling the methodology of the analysis of the content's speech, in matters of Head of Human Resources Management; also we will compare the content of speech between the banking sector and the telecoms. And finally, represent the results of discourse analysis in the form of cognitive mapping.

\section{Strategic Management Of Human Resources And Csr:}

Although the concept of SHRM is available in the literature of the early 1980s it was only during the 1990s that theoretical formulation was further specified with the use of the theory of resource dependence as main anchor. Originally formulated by Penrose (1959) and renewed by including Barney (1991) the theory of resource dependence implies that scarce resources are brave and has the original competitive advantage, and that such a benefit continues if these resources are protected against imitation transfer and substitutability. In the literature on SHRM its application has resulted in a focus on the capabilities of the development process (eg Boxall, 1996; Lundy, 1994; Mabey et al. 1998) rather than solely on the analysis of the correlation between human resources management activities and measures of financial performance. The SHRM has found these well designed as a key source of sustainable competitive advantage, when it results in particular in the skills and

${ }^{1}$ See article of Amine BOUCHIKHI et al. (2016) 
the commitment of workers management by specialists and the integration of human resource management has business strategy (Mabey et al. ibid.). The concern for the performance is even more accentuated, but rather than stipulating the existence of a direct impact of human resource management activities on performance, proponents of the strategic approach favors have an explanation for this link by the existence of concepts or variables mediators. What then are the variables that positively influence the performance. The endorsement of BASED work on the strategic approach should then be the study of the process by which human resources management systems influence the intermediate key variables that affect performance in terms of shareholder value creation (Youndt et al. 1996; Becker et al. 1997). The literature on intellectual capital (Bontis, 1996; Edvinsson and Malone, 1997; Stewart, 1997; Nahapiet and Ghoshal, 1998) was particularly put has profit to enrich such a perspective. In the year 2000, the thematic of sustainable human resource management which seems to have aroused the interest of supporters of SHRM.

It is clear that in its present state, the literature on SHRM is not sufficiently equipped to advance knowledge of human resource management that takes account of social and ethical questioning door by CSR. Traditional approaches remain predominant. The foundation work on these characterized by the centrality of concepts such as sustainability and the capabilities, or concepts from the strategic literature, more specifically the theory of resource dependence, are based on the belief that as human resources are a key factor in the ability of an organization to create and sustain a strategic advantage and as the pursuit of sustainability by including the integration of economic considerations, a social and environmental management brings such an advantage, the activities of the human resources function should be conducted in a manner that they can contribute to this objective strategic to translate into financial performance.

\section{Cross Analysis Of Reports Csr Telecommunication Companies And Banks :}

Early in the development of CSR practice in North Americans countries, it consisted of the inclusion of environmental data in the traditional financial reports, especially when this type of information included accounting implications. Subsequently, there has been the development of environmental reporting in the form of independent documents and annual report devoted solely to account for the environmental performance. The late 1990s gave rise to the proliferation of reports called «dedicated » to CSR, on the inside which we found information on corporate responsibility towards their customers, their employees (Human Resource Management) and the community (philanthropic contributions), in addition to the inclusion of data on environmental responsibility.

Conversely, Moroccan companies engaged in CSR demarches have adopted, for the most part and, from the beginning, the last practice in publishing their performance in terms of CSR with respect with all stakeholders (Employees, Community, Customers, Suppliers, Environment). This practice, certainly modern, although it remains at its embryonic stage because as we have indicated above, the CSR concept has actually seen the day in Morocco in 2005, year when the State has manifested its interest in it. So despite the transposition of a model as developed on the Moroccan expertise, we can not confirm the cultural anchor of CSR into the managerial behavior of Moroccan companies. In addition, CSR has no history in Morocco, no favorable or unfavorable antecedents, his condition is nothingness spirited to clear a path for growth.

As in the case of banks studied ${ }^{2}, 3$ telecommunication companies operant in Morocco, have CSR reports, but heterogeneous forms, the latter is still due once the voluntary nature of their publication by the three operators. Hence the need to study them from the standpoint of form first, with a spend their background then.

\subsection{Form CSR Reporting: Bi-Segment Comparison (Banks and telecoms)}

3 telecoms operators adopt different forms in their formulation of CSR reports, we will name them in this article: Companies X, Y and Z. (Table 2: Designations of telecoms reports)

\subsubsection{Telecom operator $X$ :}

Regarding the first operator and is the oldest of the telecoms operators whose creation is entirely local, chose to report on CSR, referred to as : «Rapport d'activité et de développement durable 2014 » (activity report and sustainable development in 2014), replacing «CSR » by «sustainable development », in spite of its nonseparation between its financial performance, and social responsibility, the report is consistent in terms of data on CSR and allows us to locate the company in the HR field, the word « sustainable development », has perhaps been used following the spirit of leaders, because indeed the CSR report is much talk of technology development.

\footnotetext{
${ }^{2}$ «C'est ainsi que nous avons étudié la publication de 7 banques Marocaines parmi 11 au total, toutes dans une situation de marché oligopolistique. Les 4 institutions de dépôts restantes ont été exclues, pour la simple raison qu'elles n'ont publié aucun rapport ayant attrait aux performances sociales, malgré que 2 d'entre elles, se disent responsables du point de vue social et environnemental, à travers une déclaration affichée sur leur site web. » (Thus we studied the release of seven Moroccan banks among 11 in total, all in an oligopolistic driving situation. The 4 remaining deposits of institutions were excluded, for the simple reason that they have published no report having appeal to social performance, despite that two of them say, they are responsible for the social and environmental point of view, through a statement posted on their website.) (Amine BOUCHIKHI et al., ibid)

DOI: $10.9790 / 487 X-1901014854 \quad$ www.iosrjournals.org $\quad 49 \mid$ Page
}




\subsubsection{Telecom operator $Y$ :}

The second operator who was born of years after the creation of the company X, is a product of local and international shareholders, and chose to name its CSR Report: «Rapport RSE» (CSR report), by separating it from its activity report. However, one can easily notice that the capacity of the report is very small compared to the ratio of $« \mathrm{X} »$, and several stakeholders were ignored. A report, and the least we can say, is that form of advertising brochure.

\subsubsection{Telecom operator $Z$ :}

The last operator that exists MOROCCO, is the latest of its creation, and it is also represents local and international shareholders, and currently it holds two charters that appeal to CSR: Charter customers and suppliers charter. The company « $\mathrm{Z} »$, totally ignores the human aspect in his speech on CSR.

Table 2: Designations of telecoms reports

\begin{tabular}{|l|l|l|l|}
\hline \hline \multicolumn{1}{|c|}{ Operator } & $\mathrm{X}$ & $\mathrm{Y}$ & $\mathrm{Z}$ \\
\hline Designations & & & \\
\hline activity and sustainable devellopement report & $\bullet$ & & \\
\hline Charter customers and suppliers charter & & & $\bullet$ \\
\hline
\end{tabular}

In the form of CSR reporting of Moroccan banks, we can see a similarity in the remarks with the Moroccan telecoms operators. The voluntary character in the publication of reports, and the lack of incentive to standardization, growing companies in both sectors to adopt forms that suit the, ignoring for some cases, important aspects of CSR. Here after, recall the appointment of CSR reports of Moroccan banks:

Table 1: Designations of Moroccan banks.

\begin{tabular}{|l|l|l|l|l|l|l|l|}
\hline Designations Banks & BK1 & BK2 & BK3 & BK4 & BK5 & BK6 & BK7 \\
\hline Activities and CSR Report & $\bullet$ & & & & & & \\
\hline Activity Report & & & & $\bullet$ & & $\bullet$ & \\
\hline CSR Report (independent) & & $\bullet$ & $\bullet$ & & $\bullet$ & & $\bullet$ \\
\hline
\end{tabular}

3.2. Management Human resources manager: points of convergence and divergence between the two sectors:

\subsubsection{Content analysis methodology :}

Content analysis is generally performed using the coding technique. This method consists of categorizing the text content of reports using predetermined themes, Emerging or a combination of these two types of :

- For the open coding technique, it consists of characterizing segments of texts according to emergent codes for the most part, Thus releasing the text in an intuitive way, but also constructed from the theoretical framework ;

- The axial codification consists in analyzing the frequency of the codes as well as the relations existing between the codes, Which makes it possible to sketch a schematic representation of the social representation of a given theme for a precise actor ;

- The transversal analysis is done by merging the hermeneutic units initially created on an organizational basis, And performing selective analysis operations that is by isolating codes relating to a research question in a family which is then subjected to axial coding.

- Thematic analysis: It is necessary to have a list of predefined themes and to identify in the reports the presence or the absence of these.

For the case of companies X Y and Z the thematic analysis will be used in order to be able to transpose all the themes studied for the banks, And also to effectively compare the two sectors (Telecoms and Banks). Also, the calculation and extraction of frequencies, reports on CSR in the Telecoms sector will be done manually. The second stage, Consists in the design of a cognitive mapping representing the discourse of the companies of the two sectors in the field of Responsible Management of Human Resources, As well as the convergences and discrepancies of the latter from the discourse point of view.

\subsubsection{Discourse content analysis and cognitive mapping design:}

Tableau 3 : The most frequent codes in the CSR reports of Moroccan Telecommunication companies

\begin{tabular}{|l|l|l|l|l|}
\hline \multicolumn{1}{|c|}{ Banks } & X & Y & Z & TOTAL \\
\hline Philanthropic Commitment & 65 & 15 & 0 & 80 \\
\hline Responsibility to customers & 75 & 12 & 31 & 118 \\
\hline Employee Responsibility & 51 & 9 & 0 & 60 \\
\hline Distributor networks and Accessibility & 40 & 1 & 8 & 49 \\
\hline Social inclusion / Diversity of customers & 32 & 2 & 4 & 38 \\
\hline
\end{tabular}


The table above (Tableau 3), Recapitulates all the commitments of telecoms operators in terms of CSR, Which we can summarize in the following way taking only the three most significant codes:

- The code «Philanthropic Commitment» $(\mathrm{n}=80)$ : It concerns the handling of questions affecting members of the community in the CSR reports of the 3 operators, and the only inclusion confirmed for this code can be found in the company's CSR report «X $»^{3}$

- The code «Responsibility to customers» $(\mathrm{n}=118)$ : Which concerns all frequencies, Having direct relationship with the satisfaction and the need of the customer. Obviously, its inclusion is confirmed automatically given its impact in achieving the financial performance of the 3 operators. This code is the most important.

- The code «Employee Responsibility » $(\mathrm{n}=60)$ : The latter code, which is not less important and on which our analysis is based deals with all the frequencies attracted to employees in the CSR reports, apart from the company « $\mathrm{Z}$ », The other two operators claim to be Responsible to their employees.

By comparing these three codes, with the same codes derived from the CSR reports of Moroccan banks, we can see the following results:

- First, there is an increased importance granted by the Moroccan banks to their philanthropic commitment, and much greater than the importance given to it by Telecoms operators. ${ }^{4}$

- Then, the code «Employee Responsibility ", which is the very object of our research, Confirms its inclusion in both sectors, however it remains insignificant in the "CSR vision» (The code "CSR vision » was used for passages in which companies express their definition or conception of this principle or in which they state their policy with regard to CSR, including their objectives and what they consider to be their main achievements. These passages are generally found in the introductory part of the reports, in particular in the message of management or in the extracts of testimony of employees and executives.) Executives of Telecoms operators except for $« \mathrm{Y} »^{5}$. And so from the speech point of view, only the banks say «Employers of choice ». (« Banks' CSR Vision » $n=41)$.

Tableau 4: The most frequent codes in the CSR reports of Moroccan banks.

\begin{tabular}{|l|l|l|l|l|l|l|l|l|}
\hline \multicolumn{1}{|c|}{ Banks } & BK1 & BK2 & BK3 & BK4 & BK5 & BK6 & BK7 & TOTAL \\
\hline Philanthropic Commitment & 300 & 101 & 152 & 50 & 100 & 20 & 200 & 923 \\
\hline Responsibility to customers & 55 & 41 & 35 & 52 & 60 & 11 & 72 & 326 \\
\hline Employee Responsibility & 47 & 20 & 29 & 20 & 50 & 5 & 60 & 231 \\
\hline
\end{tabular}

\subsubsection{Code analysis « Employment and Employees » In both sectors :}

The eight codes we have grouped in the family «Employment and Employees » Among telecoms operators (This family brings together all subcodes related to Employee Social Responsibility : $n=60$ Among telecoms operators), As shown in the table 5, Will be compared with those of banks (table 6).

Tableau 5: Family codes «Employment and Employees » At Telecoms operators

\begin{tabular}{|l|l|}
\hline Main code and subcodes & frequencies \\
\hline Employee Responsibility (Total subcodes) & $\mathbf{6 0 0}$ \\
\hline Training and Development & +21 \\
\hline Remuneration and benefits & +16 \\
\hline Health and security & +11 \\
\hline Data / Employment and Employees & +6 \\
\hline Employee Dialogue / Consultation & +5 \\
\hline Diversity of workmanship / equity & +1 \\
\hline Reconciliation work/ family & +0 \\
\hline
\end{tabular}

\footnotetext{
${ }^{3}$ « Par ailleurs, convaincu que la performance d'une entreprise ne saurait réellement être durable que si elle est soucieuse des besoins de la communauté, le Groupe a poursuivi sa contribution à de nombreuses initiatives humanitaires, culturelles, sportives ou de protection de l'environnement, tout en s'attachant à accompagner et à promouvoir les talents des jeunes, véritable richesse des pays. » (Moreover, convinced that the performance of a company can only really be sustainable if it is concerned about the needs of the community. The Group has continued to contribute to numerous humanitarian, cultural, sports, and environmental initiatives, While striving to accompany and promote the talents of young people real wealth of the countries.) CSR report of the operator « $\mathrm{X} »$.

${ }^{4}$ « Le Groupe a réalisé des performances satisfaisantes en 2014 grâce à ses quarante millions de clients Mobile, Fixe et Internet, qui ont tous fait le choix de ses services. La confiance que ces derniers lui témoignent récompense sa politique d'innovation, d'investissements massifs dans les technologies les plus récentes et de baisses régulières des prix pour offrir le meilleur des NTIC à tous. » (The Group achieved satisfactory performance in 2014 thanks to its 40 million mobile fixed and Internet customers, all of whom made the choice of its services. Their confidence in the company rewards its policy of innovation, massive investments in the latest technologies and steady price declines to offer the best of NICT to all.) CSR report of the operator «X».

${ }^{5}$ «....un opérateur historique de la démocratisation des télécommunications et un employeur de référence » (...A historical operator of the democratization of telecommunications and a reference employer) Word from the manager of the operator « $\mathrm{Y} »$.
}

\begin{tabular}{|c|c|}
\hline DOI: $10.9790 / 487 X-1901014854$ & www.iosrjournals.org \\
\hline
\end{tabular}


By interpreting the results of the table 5, we can make the following observations:

- First, the inclusion of the code « Responsibility to customers » in the code «Employment and Employees» Is confirmed for the company « $\mathrm{Y} »$ only, the latter combines the principles inculcated with the employees and the well-being of the client. ${ }^{6}$

- The three most important codes in the family «Employment and Employees », are the sub-codes: «Training and Development»: Which provides employees with the learning tools necessary for the practice of their profession. Professional development, on the other hand offers employees the opportunity to learn and progress in their careers.

- «Remuneration and benefits » : In the case of operators, there is a discourse tending towards social benefits rather than remuneration;

- «Health and security »: The technical nature of the business means, that the operators insist on the health and safety of the employees in their discourse on CSR. The inclusion of these three sub-codes in the code «Employee Responsibility» Is confirmed by the recurring frequencies of the three codes, and their integration into the policies and practices that the operators deem essential. However this inclusion is mitigated by a lack of "CSR vision" in the establishment of strategic policy based on Human Resources.

Table 6 : Family codes «Employment and Employees » At Banks

\begin{tabular}{|l|l|}
\hline Main code and sub-codes & frequencies \\
\hline Employee Responsibility (Total subcodes) & $\mathbf{2 3 1}$ \\
\hline Data / Employment and Employees & +85 \\
\hline Training and Development & +52 \\
\hline Remuneration and benefits & +35 \\
\hline Diversity of workmanship / equity & +30 \\
\hline Health and security & +15 \\
\hline Employee Dialogue / Consultation & +9 \\
\hline Reconciliation work/ family & +5 \\
\hline
\end{tabular}

By comparing the two sectors we can easily see first, that the code «Training and Development » in the Family «Employment and Employees» Is more frequent in the Telecoms sector, in return, and in the banking sector it is the code «Data / Employment and Employees» which is dominant, this difference could be explained by the technical nature of the trade in the first sector, and probably the search for a position of « Employer of choice » for the second. This last position is confirmed by the code «CSR vision » $(\mathrm{n}=20)$, which corroborates with the code «Employee Responsibility » in the banking sector, while it is insignificant in the telecoms sector. Also the high frequency of the code « Health and security » in the telecoms sector, explain how laborious can be in this sector.

To conclude the strategic trend of the Responsible Management of Human Resources in the sector of telecoms, would be clearly sedentary at the level of a logic of minimalist efficiency, Because the general discourse of the sector is centered on financial performance and the typical message : «We are a successful company with a well educated and highly competent workforce.» (Vuontisjarvi, 2006) ; Unlike the banking sector which would have a slight tendency towards a logic of strategic positioning which would translate into a discourse that shades the performance extending its horizon to a longer term.

\subsubsection{Cognitive mapping: Representation of the convergences and divergences of the two sectors.}

In this last part of the work it is necessary to identify the «mean/end frame », which emerges from the discourse of the two sectors, in order to deduce whether there is a real potential for renewing CSR practices towards employees. In this sense, it is first of all a question of recapitulating all the convergences and divergences between the two sectors in terms of Responsible Management of Human Resources, and of schematizing them in the form of cognitive mapping. Note that for the codes of the family "jobs and employees" we will take into consideration and compare only the first three codes (and the most important).

\footnotetext{
${ }^{6}$ « Chez Y, nous cultivons en permanence chez nos collaborateurs les principes déontologiques qui sont les nôtres. Plus que régir nos actes métiers, ces principes sont au cœur de notre culture d'entreprise. L'enjeu pour nous : toujours veiller au respect et au bien-être du client, notre principale priorité. » (At Y we constantly cultivate the ethical principles of our employees. More than governing our business, these principles are at the heart of our corporate culture. The challenge for us: Always ensure the respect and well-being of the client, our main priority.) CSR report of the operator Y.
} 
Table 7 : Convergences and divergences between the banking and telecoms sectors.

\begin{tabular}{|l|l|l|}
\hline \hline \multicolumn{1}{|c|}{ Sector } & MRHR ${ }^{7}$ OF BANKS & MRHR OF TELECOMS \\
\hline The codes & & I $^{\mathbf{9}}$ \\
\hline Training and Development & $=$ & $=$ \\
\hline Remuneration and benefits & $=$ & $=$ \\
\hline Health and security & $\neq$ & $=$ \\
\hline CSR Vision & $=$ & $\neq$ \\
\hline Co-occurrences Responsibility to Clients and Employees. & $\neq$ & $=$ \\
\hline
\end{tabular}

Figure: Cognitive mapping of convergences and discrepancies in discourse

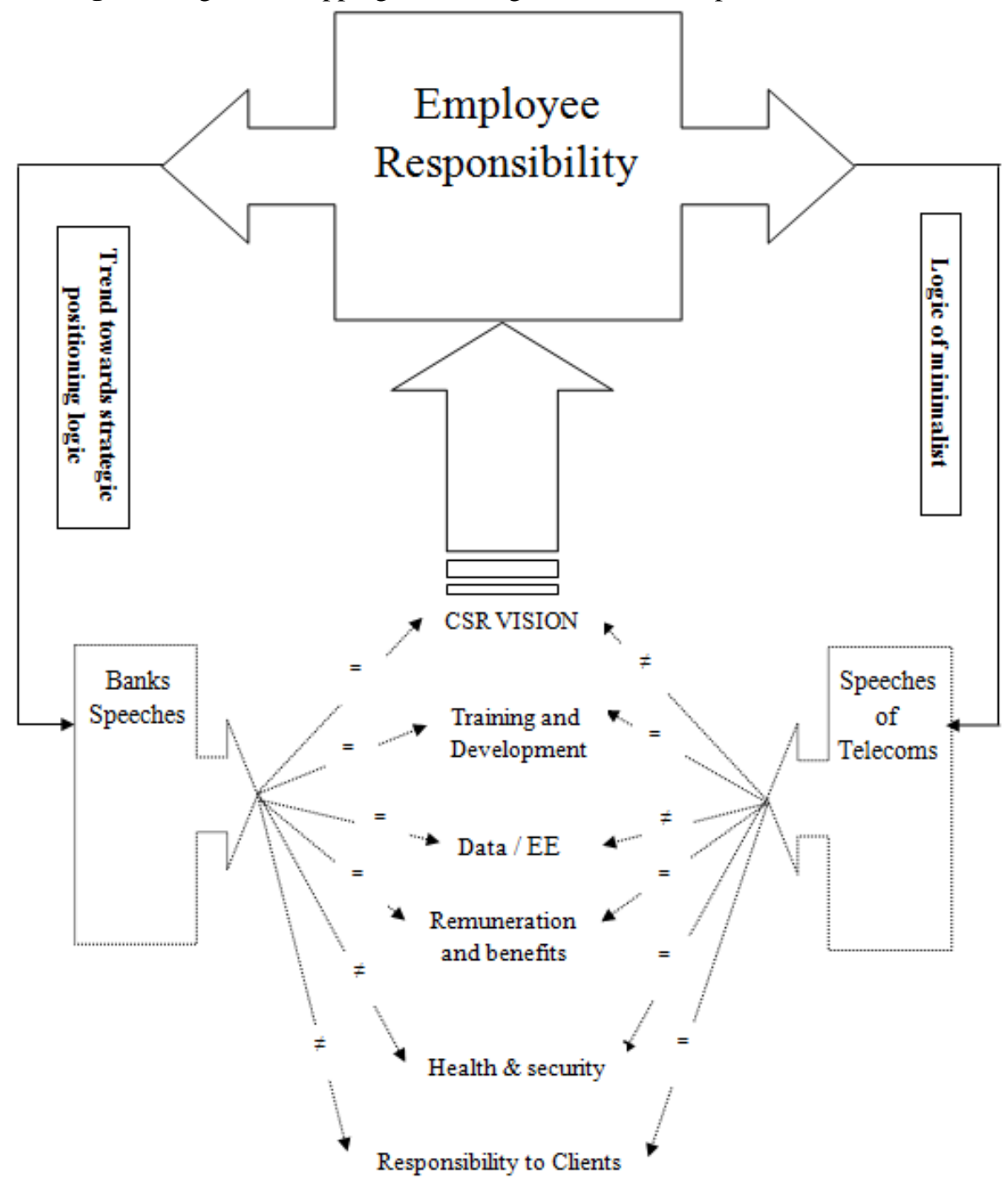

\section{Conclusion}

After calculating the frequencies of the family codes «jobs and employees », which emerge from the speech of telecoms operators, we were able to compare the latter with the discourse of the banks, particularly in terms of Responsible Management of Human Resources. This comparison could be verified also in terms of strategic trend, and allowed us to observe the effect of double speed in terms of discourse on CSR, especially in different sectors. In this sense, there is on the one hand the banking sector which has a tendency towards the logic of strategic positioning, in its discourse on social responsibility towards employees, and on the other hand there is the sector of telecoms, whose discourse reveals a logic of minimalist efficiency when it comes to employment and employees. We were finally able to make a representation of this discourse in the form of cognitive mapping.

\footnotetext{
${ }^{7}$ Management Responsible for Human Resources.

${ }^{8}$ The symbol « = » Is equivalent to the existence of a code in the sector or its great importance for the sector.

${ }^{9}$ The symbol « $\neq »$ Corresponds to the non-existent codes in the sector or insignificant codes.
} 


\section{Bibliography}

[1]. BOUCHIKHI A., et KHATOTI Y., et BADDIH H. (2016). « Discours des Banques Marocaines sur leur pratique de la gestion responsable des ressources humaines : Quelle tendance stratégique ? ». Revue d'Etudes en Management et Finance de l'Organisation, $3^{\text {ème }}$ Numéro. Juin 2016.

[2]. Barney, J.B. (1991). «Firm Resources and Sustained Competitive Advantage ». Journal of Management, vol. 17, no. 1, p.99-120.

[3]. Becker, Brian, Mark A. Huselid, P.S. Pickus et M.F. Spratt (1997). " Human resource as a source of shareholder value: Research and recommendations ». Human Resource Management, vol. 36.

[4]. Bontis, N. (1996). « There's a price on your head: Managing intellectual capital strategically ». Business Quarterly, vol. 60 no 4, p. 40-47. no 1, p. 39-47.

[5]. Boxall Peter. (1996). «The strategic HRM debate and the resource-based view of the firm ». Human Resource Management Journal, vol. 6 no 3, p. 59- 75.

[6]. De Serres Andrée, Corinne Gendron et Lovasoa Ramboarisata (2006). « Pratiques et stratégies des institutions financières en matière de divulgation d'information sur leur responsabilité sociale ». Cahier conjoint de la Chaire de responsabilité sociale et de développement durable et du Groupe interdisciplinaire de recherche en éthique financière, no 16-2006, $170 \mathrm{p}$.

[7]. Edvinsson, L. et M.S. Malone (1997). «Intellectual Capital: Realizing Your Company's True Value by Finding its Hidden Brainpower." New York: Harper Business.

[8]. Lovasoa Ramboarisata et al. (2008). «Gestion Responsable des Ressources Humaines : Evaluation théorique et analyse du discours des banques Canadiennes sur leur pratique ». Revue internationale de Psychosociologie. 2008/33.

[9]. Lundy, O. (1994). «From personnel management to strategic human resource management ». The International Journal of Human Resource Management, vol. 5 no 3, p. 687-717.

[10]. Mabey. C., G. Salaman et J. Storey (1998). "Strategic Human Resource Management." Londres : SAGE Publications.

[11]. Nahapiet, J. et S. Ghoshal (1998). « Social capital, intellectual capital, and the organizational advantage ». Academy of Management. The Academy of Management Review, vol. 23, p. 242- 266.

[12]. Penrose, Edith (1959). "The Theory of the Growth of the Firm". Oxford: Oxford University Press.

[13]. Stewart, T.A (1997). "Intellectual Capital". New York: Doubleday.

[14]. Vuontisjarvi, Taru (2006). « Corporate social reporting in the European context and human resource disclosures: An analysis of Finnish companies ». Journal of Business Ethics, vol. 69, p. 331-354.

[15]. Youndt, M.A, S.A. Snell, J.W. Dean et D.P. Lepak (1996). « Human resource management, manufacturing strategy, and firm performance ». Academy of Management Journal, vol. 39, p. 836- 866. 